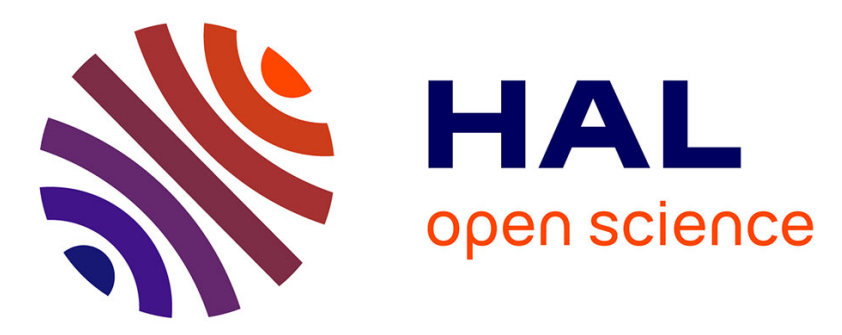

\title{
Holocene coquina beachrock from Haishan Island, east coast of Guangdong Province, China
}

Jian-Wei Shen, Jiang-Ping Long, Kevin Pedoja, Hong-Qiang Yang, Hui-Long $\mathrm{Xu}$, Jin-Long Sun

\section{- To cite this version:}

Jian-Wei Shen, Jiang-Ping Long, Kevin Pedoja, Hong-Qiang Yang, Hui-Long Xu, et al.. Holocene coquina beachrock from Haishan Island, east coast of Guangdong Province, China. Quaternary International, 2013, 310, pp.199-212. 10.1016/j.quaint.2013.05.011 . hal-00931933

\section{HAL Id: hal-00931933 \\ https://hal.science/hal-00931933}

Submitted on 30 Sep 2019

HAL is a multi-disciplinary open access archive for the deposit and dissemination of scientific research documents, whether they are published or not. The documents may come from teaching and research institutions in France or abroad, or from public or private research centers.
L'archive ouverte pluridisciplinaire HAL, est destinée au dépôt et à la diffusion de documents scientifiques de niveau recherche, publiés ou non, émanant des établissements d'enseignement et de recherche français ou étrangers, des laboratoires publics ou privés. 


\title{
Holocene coquina beachrock from Haishan Island, east coast of Guangdong Province, China
}

\author{
Jian-Wei Shen ${ }^{\mathrm{a}, *}$, Jiang-Ping Long ${ }^{\mathrm{b}}$, Kevin Pedoja ${ }^{\mathrm{c}}$, Hong-Qiang Yang ${ }^{\mathrm{a}, \mathrm{d}}$, Hui-Long $\mathrm{Xu}^{\mathrm{a}}$, \\ Jin-Long Sun ${ }^{\mathrm{a}}$ \\ ${ }^{a}$ CAS Key Laboratory of Marginal Sea Geology, South China Sea Institute of Oceanology, Chinese Academy of Sciences, Guangzhou 510301, China \\ ${ }^{\mathrm{b}}$ The Second Institution of Oceanography, State Oceanic Administration, Hangzhou 310012, China \\ ${ }^{\mathrm{c}}$ Laboratoire de Morphodynamique Continentale et Côtière, CNRS, Université de Caen, 14000 Caen, France \\ ${ }^{\mathrm{d}}$ University of Chinese Academy of Sciences, Beijing 100049, China
}

Coquina beachrock, with a thickness of $10 \mathrm{~m}$ and an exposed surface area covering $3.4 \mathrm{~km}^{2}$, is well developed along the southern coast of Haishan Island on the east coast of Guangdong Province, South China. Part of the deposit not treated in this study also extends under the surface of the sea. The coquina beachrock was deposited in a large embayment semi-enclosed by palaeocoastal hills and islands, but with good marine circulation. Holocene strata on Haishan Island demonstrate a mixed carbonate/sili-ciclastic regime in a series of fining- and deepening-upward shelly limestone successions. Mass accumulations of whole and fragmented mollusc shells are the most remarkable features expressed throughout the series. Coralline red algae are commonly found overgrowing the bivalve bioclasts. Other bioclasts include gastropods, coralline red algae, bryozoans, foraminifera, and scleractinian coral. Cement is well developed within the interstices formed by the bioclasts, showing two or three generations of development. On both a qualitative and quantitative basis, the consecutive coquina series document an overall shallowing-upward pattern of beachrock deposition, which was strongly influenced by marine transgression on Haishan Island. Dating by AMS ${ }^{14} \mathrm{C}$ indicates an age in the Middle to early Late Holocene for these coquina beachrock deposits. Siliciclasts incorporated within the beachrock deposits mainly consist of quartz grains. Not fully hardened, the binding cement is high in calcium carbonate, including aragonite mud, fibrous aragonite and granular calcite. Such carbonate deposits dominated by mollusc bioclasts with quartz grains indicate a pattern of littoral sedimentation. The massive coquina beachrock on the southern coast of Haishan Island formed during Middle to early Late Holocene time, and repre-sents a highstand of sea level from $4000 \mathrm{BP}$ to $2800 \mathrm{BP}$ with short-lived and rapid sea level fall.

\section{Introduction}

Coquina is a term of Spanish origin for rocks composed primarily of disarticulated cockleshells, or other shellfish. It occurs as a coarse-grained, porous, friable variety of bioclastic limestone with a dominant component of whole and fragmented shells. Typically, the shells are bivalves and gastropods. Coquina consists of almost completely mechanically transported shell debris with little or no matrix (Schmidt et al., 1979; Kenworthy and Santucci, 2006). Shell bioclasts are loosely cemented, so that the rock appears very porous. Holocene beachrocks are widely distributed over an

* Corresponding author. Department of Marine Geology, South China Sea Institute of Oceanology, Chinese Academy of Sciences, 164 West Xingang Road, Guangzhou 510301, Guangdong, PR China.

E-mail address: jwshen@scsio.ac.cn (J.-W. Shen). extensive area from the northern coast of the South China Sea in the north to the Nansha (Spratly) Islands in the south. More than 44 locations of beachrock were reported along the coast of Fujian, Guangdong and Guangxi Provinces (Bi et al., 1987; Li, 1988; Wang, 1992; Bi and Yuan, 1994; Yang and Yang, 1996; Wang, 1997; Li and Fen, 1998; Zhan et al., 1998; Wang and Wu, 1999). Among these, the coquina beachrock along the southern coast of Haishan Island is unique in development scale and composition (whole and fragments shells with quartz grains). Beachrock, including coquina beachrock, and its significance in local tectonics, climatology, and sea-level change along the northern coast of the South China Sea, has been a focus of attention since the late 1970s. Several authors (Huang et al., 1978; Zhao et al., 1978; Zeng, 1980; Xie et al., 1983; Yuan and Bi, 1984; Zhao et al., 1984; Li, 1988; Yang and Yang, 1996; Zhan, 2004; Sun et al., 2006) studied preliminarily the texture, structure, cementation and temporal and spatial distribution of 
various beachrocks in south China, and discussed briefly their relationships with neotectonic events, sea-level changes, and coastal hazards. The previous dating data of the Chinese beachrocks were generally based on conventional ${ }^{14} \mathrm{C}$ analyses.

Bi et al. (1987) described the sedimentary facies of beachrock in Haishan Island. Li (1988) discussed the paleogeographic significance of Holocene beachrock in South China, and revealed that the beachrocks are mostly mid-Holocene in age based on ${ }^{14} \mathrm{C}$ dating. Zhan et al. (1998) studied the characteristics of Holocene beachrocks and sea-level changes along the coast of eastern Guangdong Province, and divided them into five development stages. Despite these contributions, some important aspects regarding the origin and spatial-temporal distribution of Chinese Holocene coquinas remain elusive. Topics that deserve further study include variations in the types and composition of beachrocks or coquina beachrock, as well as plausible explanations for the relationships between their petrologic characteristics and water energy, between processes of cement formation and climate, and between coquina beachrock development and sea-level changes as related to the positions of former coastlines.

This paper examined the depositional succession of coquina beachrock on the southern coast of the Haishan Island with the goal of providing detailed descriptions of its biota and variations in the cements found between mollusc shell fragments/bioclasts. This study also evaluates the relationships between coquina beachrock development and sea-level changes, as well as coastal uplift based on the AMS ${ }^{14} \mathrm{C}$ dating.

\section{Geographic setting}

Located in a semi-isolated bay on the east coast of Guangdong province near Nanao Island in Raoping County (Fig. 1), Haishan Island is about $12 \mathrm{~km}$ long in the NE direction with a maximum width of $6 \mathrm{~km}$ (Fig. 2). It is situated in a low-coastal zone with intertidal mud flats modified by human activities (Pedoja et al., 2008). The bay is flanked by lands in the east, north and west. Haishan Island is composed of two separated smaller islands:
Haibei island and Hainan island. Bedrock exposed in hills on the island is the Yanshanian granite. The lowlands are covered by marine fine- to medium-grained sands of mid-Miocene age. A $2.5 \mathrm{~km}^{2}$ coastal plain, $3 \mathrm{~km}$ long from east to west and $0.8 \mathrm{~km}$ wide from south to north, runs along the southern part of Haishan Island, where a large area of coquina beachrock carbonates are covered by modern sands and soils. Sporadic instances of marine notches occur eroded in the ancient coastal bedrock at the junction between the coastal plain and neighboring hills.

Marine terraces occur on the northeastern part of Haishan Island near Aobian village (Fig. 2) (Pedoja et al., 2008). Above a small modern abrasion platform, the lowest marine terrace is 25 m wide with a shoreline angle at $20 \pm 3 \mathrm{~m}$ above mean sea level. Adjacent is a $2025 \mathrm{~m}$ wide flat morphology with a scarp at $28 \pm 3 \mathrm{~m}$ above mean sea level, which is interpreted as a second terrace. At a higher elevation, a third marine terrace is $60 \mathrm{~m}$ wide with a shoreline angle at an elevation of $40 \pm 5 \mathrm{~m}$. The upper part of this deposit is associated with a marine notch at an elevation of $8 \pm 1 \mathrm{~m}$. Paleoabrasion platforms sit on intrusive granites that are of lower and middle Mesozoic age (Guangdong Geological Survey, 1965). No marine deposits are associated with the Haishan terraces, but their marine origin is not doubted, because honeycomb weathering, marine tafoni, and former sea stacks and tidal pools are present on their surfaces (Pedoja et al., 2008).

The Holocene coquina beachrock was deposited within an inlet on the southern part of Haishan Island (Fig. 2). It extends over a 2.8$\mathrm{km}$-long stretch of the coast, reaching a maximum distance of $0.8 \mathrm{~km}$ inland to form a marine plain $2.5 \mathrm{~km}^{2}$ in area. The subaerial extent of coquina beachrock left onshore after repeated episodes of subsidence (diagenesis) and uplift (erosion) is about $10 \mathrm{~m}$ thick and covers $1,100,000 \mathrm{~m}^{2}$. Along the present intertidal zone, shell fragments/ bioclasts and sands are consolidated or semi-consolidated, forming shelly limestone exposed in a small steep scarp (Fig. 3). The coquina beachrock also extends near shore (Fig. 3 ), but its extent is difficult to estimate due to a muddy tidal flat. Inland, shelly limestone beds also are covered by sands and soils reworked as a result of human agricultural activities. The coquina beachrock is composed of shell

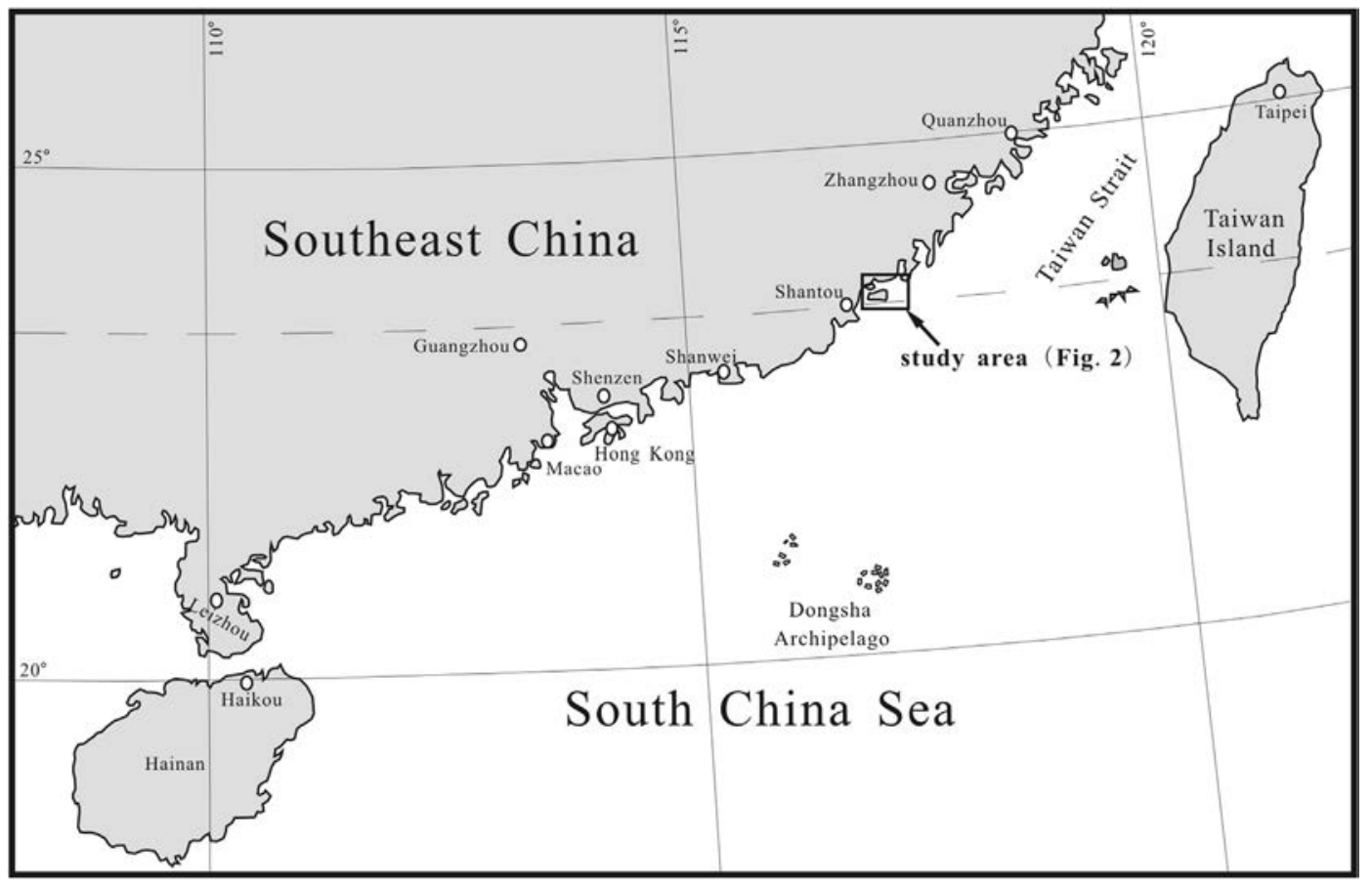

Fig. 1. Map showing the region on the northern coast of the South China Sea and location of the study area (Fig. 2). 


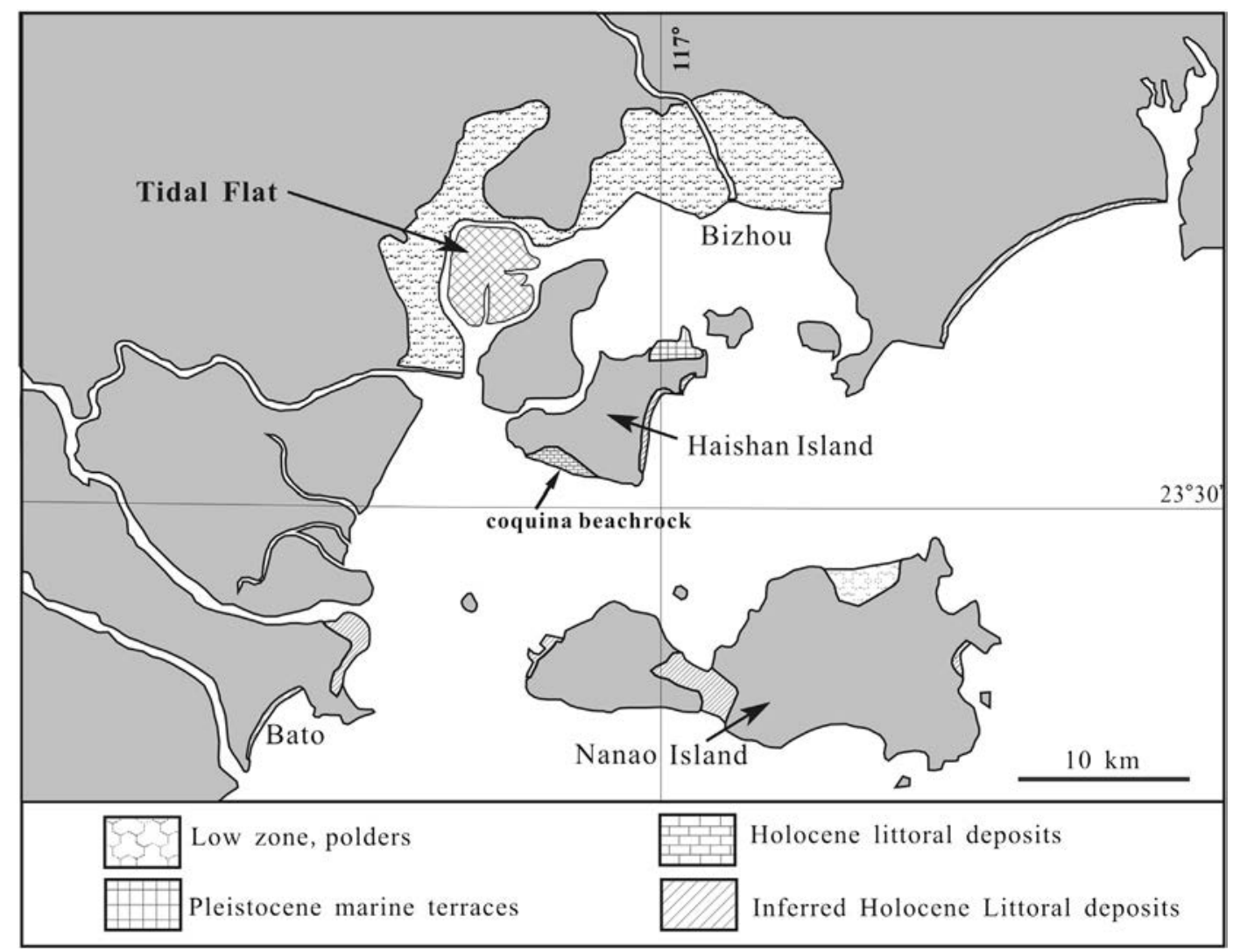

Fig. 2. Holocene littoral deposits on Haishan Island and its vicinity (from Pedoja et al., 2008).

fragments and bioclasts, biotic grains, quartz grains, and rare fine gravels. Described as beachrock and dated by Bi and Yuan (1988), these deposits on the southern part of Haishan Island do not fit the established view of beachrock (Purser, 1980) because they include both abundant shells and extensive marine and terrigenous sands from a wave-built terrace. Hence, the deposit is more appropriately interpreted as a shallow-water coquina beachrock. Bivalves and gastropods collected for AMS ${ }^{14} \mathrm{C}$-dating from Bed 5, Bed 10 and Bed 12 , yielded ages of $3720 \pm 30 \mathrm{BP}, 3530 \pm 30 \mathrm{BP}$, and $2910 \pm 30 \mathrm{BP}$, respectively. In addition, a sample collected from the inner edge of the marine plain (sample HL-8, Fig. 3) representing the top of coquina beachrock (corresponding to the Bed 13) provided a non-calibrated age of $2810 \pm 90 \mathrm{ka}$ (Pedoja et al., 2008).

\section{Climate}

Haishan Island has a sub-tropical monsoon climate with an average air temperature of $28{ }^{\circ} \mathrm{C}$ in the summer and $12{ }^{\circ} \mathrm{C}$ in the winter. The monsoon distinctly impacts the area's temperature and rainfall. Easterly winds are most common throughout much of the year. From April to September, winds and rain are brought from the continental mainland of China. Water temperatures in the bay next to southern Haishan Island range between $29{ }^{\circ} \mathrm{C}$ (summer) and $14{ }^{\circ} \mathrm{C}$ (winter). The average tidal range is $0.78 \mathrm{~m}$. The average rainfall in the study area amounts to $1724 \mathrm{~mm} / \mathrm{year}$.

\section{The characteristics of Haishan coquina beachrocks}

The coquina beachrock succession is mainly exposed along Waitoupu beach on the southern coast of Haishan Island, about 1.2$1.5 \mathrm{~km}$ from Huanglong Town to the north. Deposits form a wide coastal plain, about $2.5 \mathrm{~km}^{2}$, extending from the foothills in the north to the sea in the south. The deposits are concealed offshore by a muddy tidal flat. The distribution and characteristics for the submarine part of the deposit are unknown due to the difficulties of submarine survey work.

\subsection{Occurrences}

Based on geomorphologic features, outcrops of coquina beachrock can be divided superficially into two parts along an east-to-west distribution. The eastern part shows small-scale local cross bedding imbricated in distinct layers that tilt seaward. Outcrops occur from the highest tide line to the submarine area on the coast, extending discontinuously over about $1 \mathrm{~km}$. The upper part of this occurrence has been destroyed due to mining activities, so it is difficult to evaluate the original thickness. However, according to outcrop analysis, the eastern part had a smaller initial thickness than the western part. The coquina beachrock from the western outcrops forms a long and steep berm near the high-tide line. It extends over a $1.2-\mathrm{km}$ stretch of the coast from east to west, ranging from 10 to $30 \mathrm{~m}$ in width at the top. The thickness of the beachrock berm is $1.2-1.8 \mathrm{~m}$ on the seaward side. It is $3.65 \mathrm{~m}$ thick on the landward side, as measured on the vertical scarp made by human activities. The highest elevation of the beachrock berm is $7 \pm 2 \mathrm{~m}$ above mean sea level.

The inland extension of the coquina beachrock is mostly covered by soil and aeolian sand, but some outcrops occur in ponds and ditches (Fig. 4) showing well-developed beds with low-angle tilting toward the sea $\left(5^{\circ}-10^{\circ}\right)$. The thickness of the coquina beachrock in these outcrops never exceeds $2.5 \mathrm{~m}$, but the lowest level is not exposed. Typically, the basal part of the coquina beachrock is loose and well-bedded. A vertical section on the steep face of coquina beachrock berm at the shore shows distinct layering corresponding to those beds (Figs. 5 and 6 ) on the landward face. The top bed of 


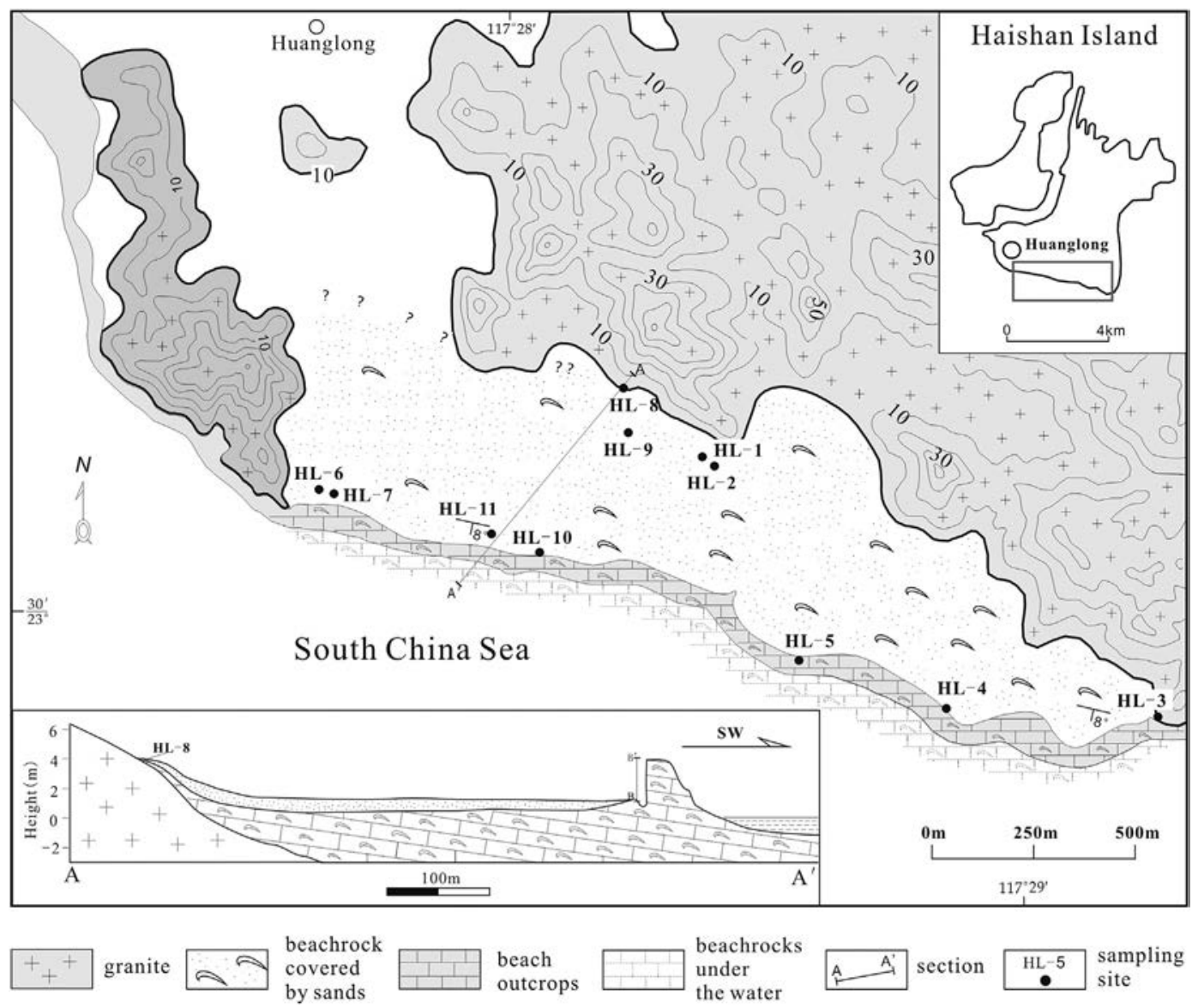

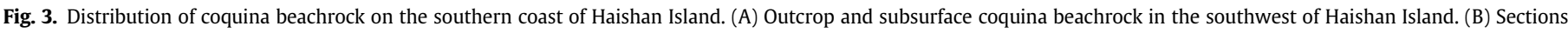
through the outcrop and subsurface coquina beachrock $\left(A-A^{\prime}\right)$ and the coquina beachrock depositional succession $\left(B-\mathrm{B}^{\prime}\right)$.

the coquina beachrock also occurs at the foot of the hill slope, the farthest extending site of coquina beachrock development towards the inland, at an elevation of $8 \pm 1 \mathrm{~m}$.

\subsection{Depositional succession}

Detailed mapping and measurements of strata reveal that the coquina beachrock all along the southern coast of Haishan Island

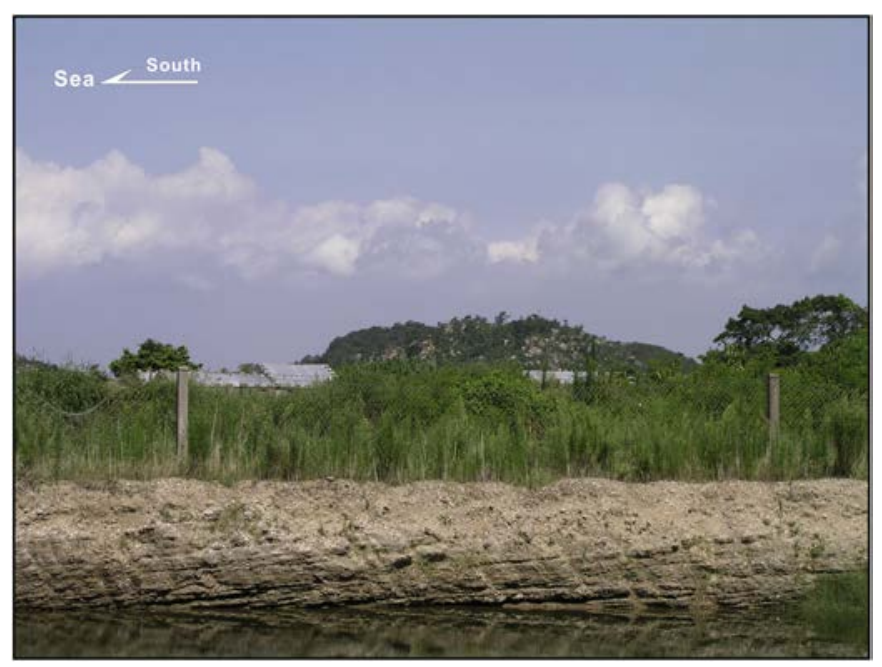

Fig. 4. A section in a fish pond dug up by human activities showing well-developed beddings with low-angle tilting to the sea $\left(5^{\circ}-10^{\circ}\right)$. was deposited under the same environment, and the geomorphologic variations are the result of erosion and human-made destruction. It was possible to study several geological sections at $90^{\circ}$ to the coastline from the foot of the hill slope to the sea (Fig. 3, Section $A-A^{\prime}$ ). However, these sections fail to expose the lower part of the coquina beachrock. Distinct beds tilting toward the sea, generally at an inclination of $5^{\circ}-10^{\circ}$, are continuously developed outward from the foot of the hill slope. A section measured from the more western part of the coquina beachrock shows cross bedding. The steep face of the coquina beachrock resulted from human excavation for building materials, where a vertical section (Fig. 3, Section $B-B^{\prime}$ ) features well-developed sedimentary characteristics measured for their depositional history (Fig. 5). Thirteen beds were identified and distinguished, including beds with well-developed layers and indistinct beddings (Fig. 6). Two coquina beds (Bed 5 and Bed 8) contain extensive amounts of relatively complete shells that account for $80 \%$ of the rock volume (Fig. 7). Locally, whole shells can be observed, but they are mostly disarticulated, indicating transportation. The bed thicknesses are thin- to medium, ranging from $8 \mathrm{~cm}$ to $40 \mathrm{~cm}$, but the uppermost bed (Bed 13) is more than $2 \mathrm{~m}$ in thickness.

Section (B-B' $\mathrm{B}^{\prime}$ ) at a small scarp (Figs. 3 and 6 ) is more than $4 \mathrm{~m}$ in thickness. The footwall is partly covered by soil and sand, and should be at the same depositional level as found in Bed 1. Therefore, the lowest part of Bed 1 is not wholly exposed in the measured section $\left(B-B^{\prime}\right)$. The base of the section (Bed 1) consists of bivalve shell fragments/bioclasts, quartz grains, gastropod fragments, and foraminifera. Bivalve shell fragments occur as small flakes, generally deposited parallel to the bedding plane, and poorly rounded 


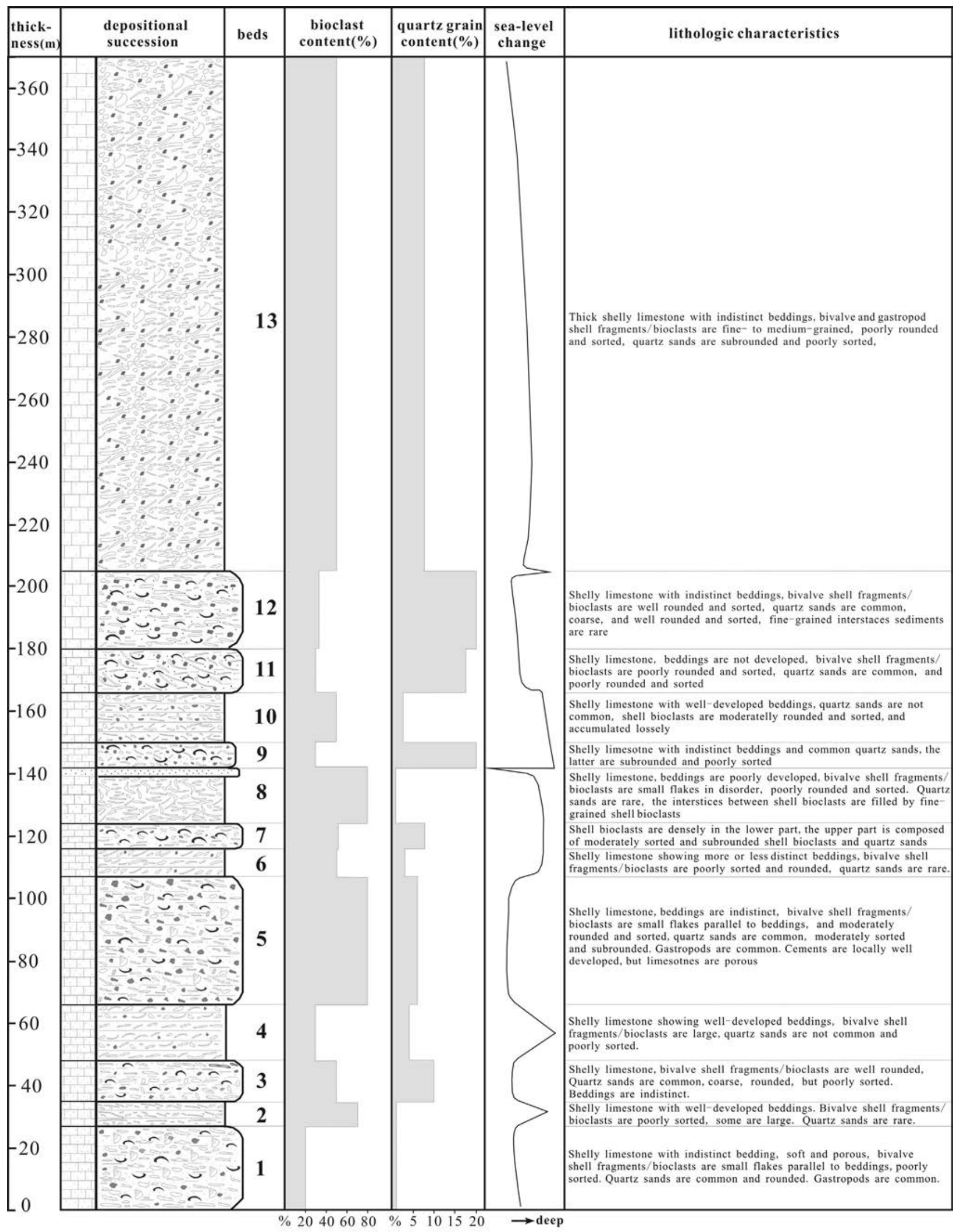

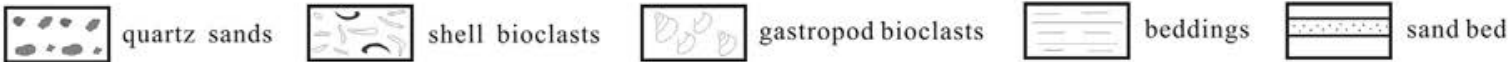

Fig. 5. Depositional succession of the coquina beachrock (B-B' section) in the Hanshan Island, eastern Guangdong Province. 


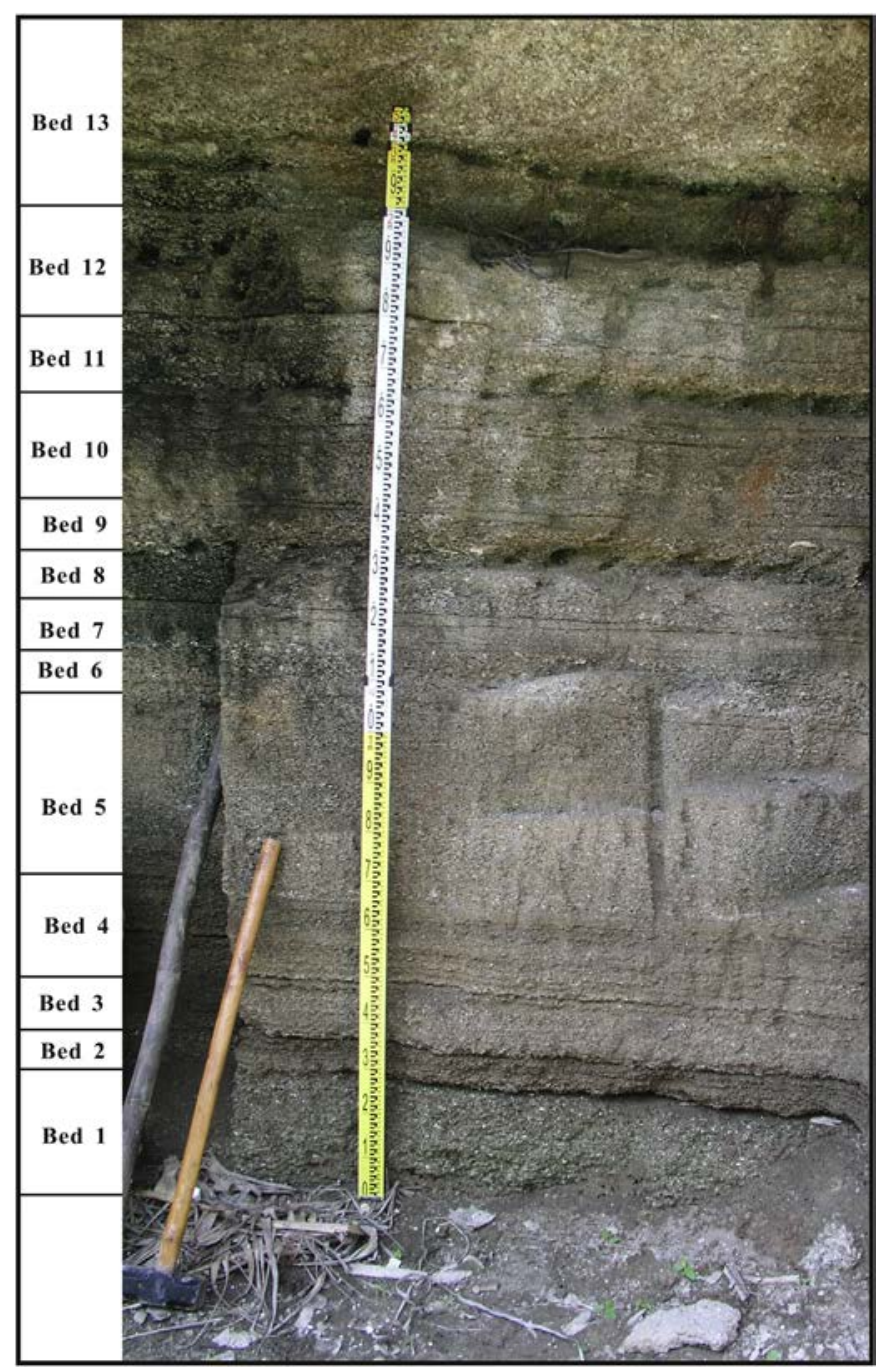

Fig. 6. On the steep of coqunia beachrook resulted from human collecting building materials, a vertical section, more than $4 \mathrm{~m}$ in thickness, show well-developed sedimentary features.

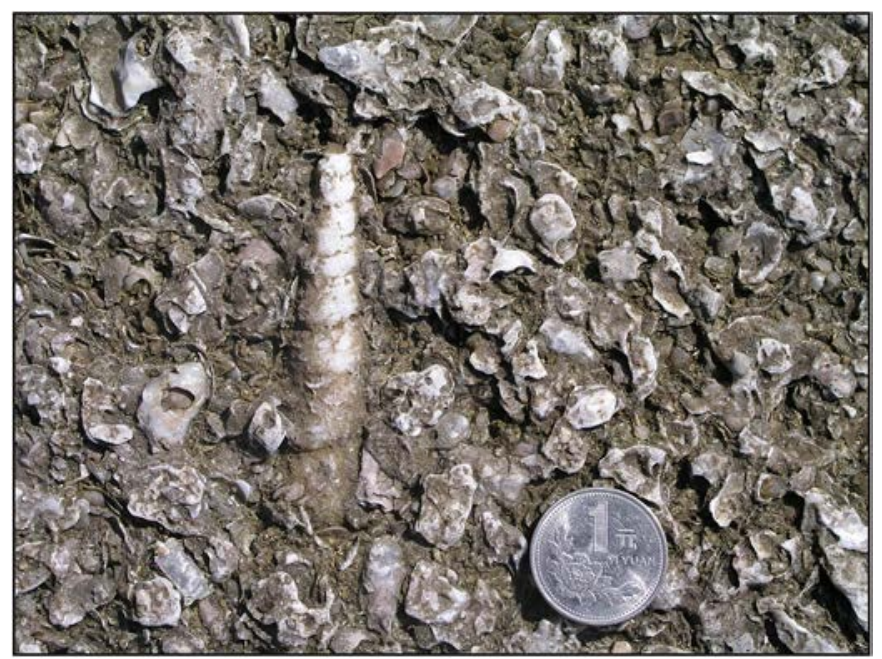

Fig. 7. Field photo of Bed 5 , showing relatively whole bivalve and gastropod shells that contribute more than $80 \%$ of the rock volume, the coin diameter is $24.5 \mathrm{~mm}$. and sorted. Quartz grains are common and rounded and sorted. Bed 2 is composed of thin- and well-bedded shell fragments/bioclasts with rare quartz grains. Layers are well developed, and bivalve shell fragments/bioclasts are poorly sorted. Bed 3 is thicker than Bed 2, and consists mainly of bivalve fragments/bioclasts and common quartz grains (Fig. 8a). Bivalve fragments/bioclasts are well rounded but moderately sorted. Quartz grains are rounded but poorly sorted, and layers are indistinct. Bed 4 has a greater thickness than both Bed 2 and Bed3, with well-developed layers. Bivalve shell fragments/bioclasts are larger than that in Bed 2 and Bed 3, well rounded but moderately sorted. Quartz grains are not common, but poorly sorted. The thickness of depositional beds increases from Bed 2 to Bed5; and Bed 5 grades into a more than $40-\mathrm{cm}$-thick bed. Bivalve shell fragments/bioclasts are small flakes parallel to bedding planes, and are moderately rounded and sorted (Fig. 8b). Quartz grains are common, moderately sorted and sub-rounded (Fig. 8b). Cements are locally well developed, but the limestone is porous.

The next package (beds 6-8) shows another set of upwardly thickening beds, where bivalve shell fragments/bioclasts become increasing abundant upward. Bed 6 shows more or less distinct layers, bivalve shell fragments/bioclasts are poorly rounded and sorted, and quartz grains are not common. Quartz grains are common in Bed 7. Shell bioclasts are accumulated densely in the lower part of the Bed 7, and the upper part is composed of moderately sorted and sub-rounded shell bioclasts and quartz grains. In Bed 8, bivalve shell fragments/bioclasts are mass accumulated and more than $80 \%$ of the rock volume. They occur as flakes in a disordering way, poorly rounded and sorted. Layers or beddings are not distinct. Quartz grains are rare.

The upper part of the package (beds 9-13) shows an upwardthickening depositional succession. Bed 9 shows indistinct beddings, shell fragments and bioclasts are abundant and moderately to well-rounded and sorted. Quartz grains are common, and moderately to well-rounded and sorted. Bed 10 have welldeveloped layers. Bivalve shell fragments/bioclasts are moderately rounded and sorted, and quartz grains are less common (Fig. 8c), and sub-rounded and poorly sorted. No distinct layers occur in Bed 11, and quartz grains are more common compared with Bed 9 and Bed 10. Both bivalve shell fragments/bioclasts and quartz grains are poorly rounded and sorted. Bivalve shell fragments/bioclasts and quartz grains in Bed 12 are well rounded and sorted (Fig. 8d), quartz grains are more common than that in Bed 11, and fine-grained sediments in the interstices are rare. Bed 13 is a thick coquina beachrock, containing fine- to medium-grained bivalve shell fragments/bioclasts and quartz grains, both of which are poorly rounded and sorted. Layering is not distinctly developed. The depositional succession of the coquina beachrocks $\left(B-B^{\prime}\right.$ section) is shown in Figs. 5 and 6.

In general, distinct layers are relatively well developed in the lower and middle part of the succession, particularly in Bed 2, Bed 4, Bed 6 and Bed 10. However, layers are more poorly developed in the upper part, probably due to a change in depositional rate. Quartz grains typically are more common in the units without bedding, but an exception is found in Bed 8, where layers are not developed and quartz grains are rare. This unit may signal an event of rapid deposition under storm conditions.

Poorly rounded and sorted shell fragments/bioclasts and wellrounded and sorted quartz grains in Bed 1 are factors interpreted to represent a moderate water energy and shallow water depositional condition, and the distinct layers, unsorted shell fragments/ bicolasts and rare quartz grains in Bed 2 indicate lower water energy and deep-water condition. Bed 3 is interpreted as a shallow water and higher water energy deposition because of well-rounded and moderately sorted shell fragments/bioclasts and common, 

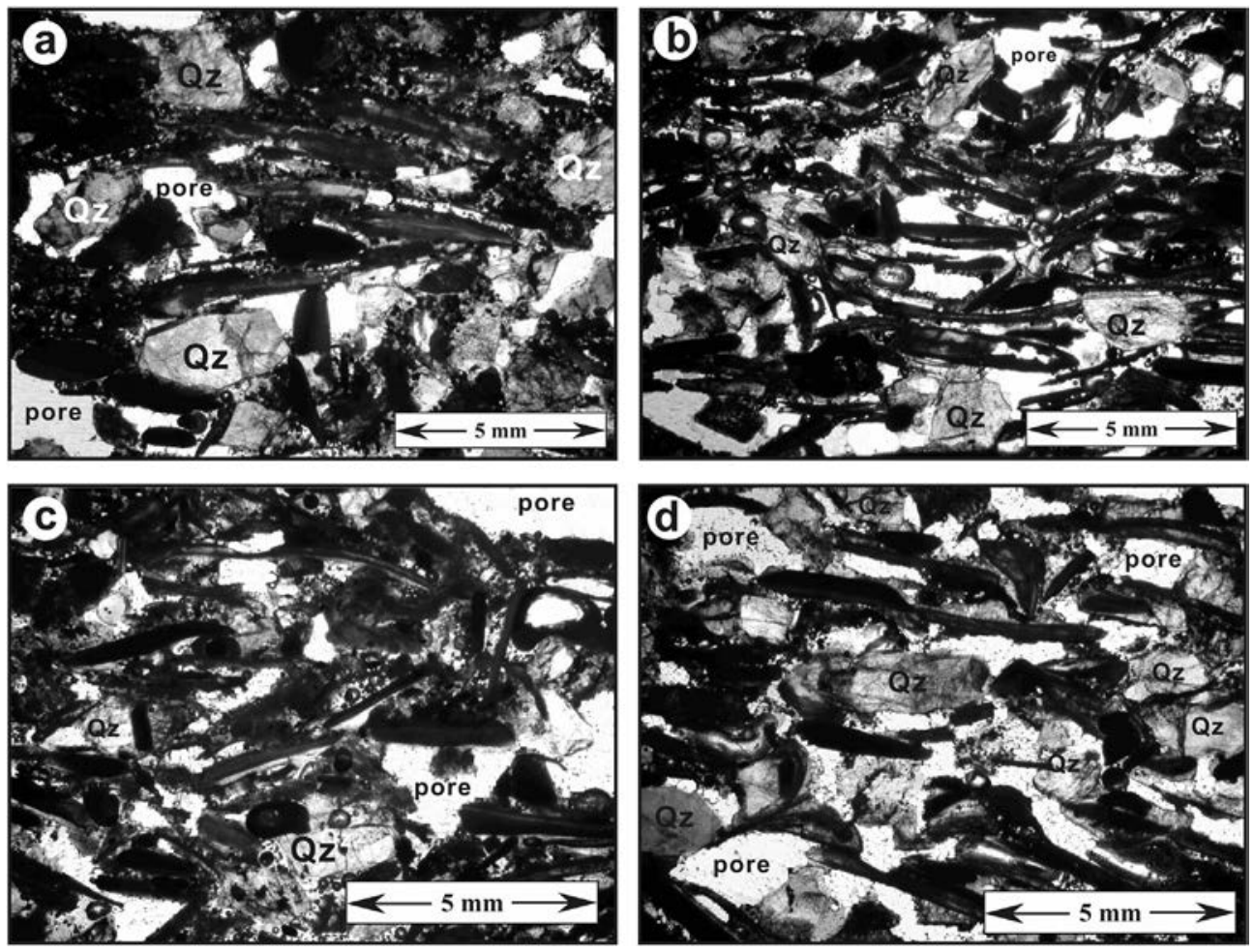

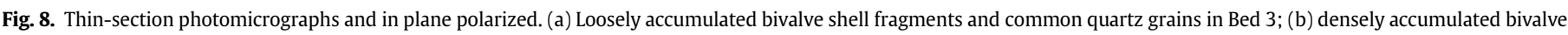

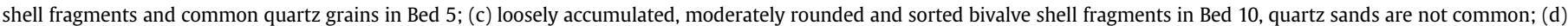
well rounded and sorted bivalve shell fragments and quartz grains in Bed 12 .

rounded and poorly sorted quartz grains. Bed 4, with distinct layers, is a deposition of deep water and moderate water energy setting with well-rounded and moderately sorted shell fragments/bioclasts and rare and poorly sorted quartz grains. Bed 5, the top part of thickening-upward beds, suggests higher-energy and shallowwater conditions during an interval of rapid accumulation as the deposition is composed of moderately rounded and sorted shell fragments/bioclasts and common, moderately sorted and subrounded quartz grains. The package (Bed 6 to Bed 8) shows an increased thickness and shell bioclast content. Quartz grains are generally rare, but are common in Bed 7. Shell bioclasts are commonly poorly rounded and sorted and quartz grains are generally sub-rounded. These characteristics represent a moderately to high-energy, moderate to high depositional rate, and a change from a deep to relatively shallow environment. A reddishbrown, 3-5 cm thick sand bed occurs at the top of Bed 8 (Fig. 5), indicating a depositional hiatus of coquina dominated beachrock. Moderately to well-rounded and sorted shell bioclasts and common quartz grains in Bed 9 reveal deep water and moderately to high water energy condition. Bed 10 , with more or less distinct beddings, reflect a depositional condition with relatively deep water, low energy and a low depositional rate as the shell fragments/bioclasts are moderately rounded and sorted and quartz grains are less common. Bed 11, with increased quartz grains, was deposited under shallow water and moderately to strong energy, as demonstrated by poorly rounded and sorted shell fragments/bioclasts and quartz grains as well as indistinct bedding. Bed 12, consisting of abundant quartz grains and well-rounded and sorted shell fragments/bioclasts, represents a deposition formed by shallow water and relatively strong water energy. Bed 13, with greater thickness than the lower beds, has thin- to medium-grained and poorly rounded and sorted shell bioclasts and quartz grains, reflecting a low- to moderate water energy and shallowing-upward depositional setting.

\subsection{Composition and texture}

Coquina beachrocks on the southern coast of Haishan Island are mainly composed of two types of sediments: fragments/bioclasts of bivalves, gastropods, red algae, bryozoans and benthic foraminifera, as distinguished from terrigenous quartz and feldspars. The former is autochthonous in origin and derived from a marine biota in a semi-isolated bay. The latter comes from the bedrock and subaerial coastal sediments due to water and wind erosion. Sand occurs everywhere, but rocks are mainly represented by shelly limestone of various grades determined by shell deposits.

Biotic grains are dominated by bivalve shell fragments/bioclasts, but in some intervals gastropods occur. They are generally more common in the upper part of the succession. Bivalve fragments/ bioclasts are more or less randomly oriented or deposited with their c-axes perpendicular to bedding planes that show irregular fine-bedding textures. Erosional remnants and pockets are occasionally observed, but no secondary calcite was deposited within these cavities, indicating that the coquina beachrock was formed in an alkaline or slightly alkaline environment unfavorable for the dissolution of shell fragments/bioclasts. Bivalve shell fragments/ bioclasts generally present a better-preserved wall structure and lack boring holes and micrite envelopes, suggesting little microbial activity. Dissolved holes are rarely developed in some shell fragments, especially in those overgrown by coralline red algae. Most of the bivalve fragments show margin-parallel lines in shell cross sections. The internal structure of shells is preserved, but the original calcite in some shells is transformed into neomorphic calcite. The latter formed unfilled voids when the aragonite was leached.

Gastropod fragments are uncommon through the entire section $\left(\mathrm{B}-\mathrm{B}^{\prime}\right)$, but they do occur as fine- to medium-sized $(0.150-0.5 \mathrm{~mm})$ bioclasts. In the top part of the coquina beachrock, however, complete gastropods typically are well preserved (Fig. 7). Coralline red 
algae are common in the lower part of the coquina beachrock succession, but occasionally occur in the upper beds. For the most part, they encrust the bivalve shell fragments (Figs. 9a and 10a), but some occur as bioclasts between shell fragments (Fig. 9c). Red algae encrusted on bivalve shell fragments generally show partial dissolution that resembles biomoldic pores (Figs. 9a, b and 10a). Red algae also exhibit a dense cell structure oriented parallel to the long axis of grains (Fig. 9b, d), and some present a series of light and dark growth bands in longitudinal section (Fig. 9c and 10a). Fragments of scleractinian coral and bryozoan bioclasts are rare. Coral walls are well preserved (Fig. 10b), but walls and septa are completely neomorphosed with fibrous calcite (Fig. 10b). Bryozoans provide bioclasts that reveal typical zooecia on broken skeletons. Foraminifera are well preserved and are dominated by monotypic species with bright shiny shells decorated by some spines, indicating they were not transported, but were buried in situ. These foraminifera include euryhalinous species (Ammonia annectens, Ammonia beccarii, Ammonia sp. and Elphidium advenum), inshore, warm shallow water species (Cellanthus cralicalatum and Elphidium hispidulum), and tropical shallow-water species (Pseudorotalia schroeterianu).

Terrigenous sediments are composed of quartz and feldspar, both of them are coarse- and fine-grained. Coarse clasts generally are rounded, but the fine clasts occur throughout the entire succession of coquina beachrock. The fine clasts are sub-edged, but some are sub-rounded or even well rounded. These two-sized, poorly-sorted grains may indicate autochthonous and allochthonous origins. Corresponding to the upward-thinning or upwardcoarsening change in terrigenous clasts, the sizes of bioclasts also become upwardly smaller or larger. A $3-5 \mathrm{~cm}$ thick sand bed occurs in the middle part of the coquina beachrock succession, probably indicating a depositional hiatus. Low-angle cross bedding is common in the lower part of the coquina beachrock succession, but it is not common in the upper part, where coquina beachrock is more fragmented with abundant solution cavities.

The amount of shell fragments and other bioclasts is variable throughout the succession. Generally, the lower part contains more shell fragments and bioclasts than the upper part (Table 1). The shell fragments are relatively well sorted in the lower part, but poorly sorted in the upper part (Table 1). Quartz grains are upwardly more abundant, are particularly common in specific beds, and become well-rounded in the upper part of section (Table 1).

Table 1

Content, sizes and roundness of shell fragments/bioclasts and quartz grains in the coquina beachrock deposits, Haishan Island, eastern Guangdong Province.

\begin{tabular}{|c|c|c|c|c|c|}
\hline \multirow[t]{2}{*}{ Samples } & \multicolumn{2}{|c|}{ Fragments/bioclast } & \multicolumn{3}{|c|}{ Quartz grain } \\
\hline & $\begin{array}{l}\text { Content } \\
(\%)\end{array}$ & Size $(\mathrm{mm})$ & $\begin{array}{l}\text { Content } \\
(\%)\end{array}$ & $\begin{array}{l}\text { Size } \\
(\mathrm{mm})\end{array}$ & Roundness \\
\hline HS-1 (Bed 1) & 20 & $3.7-4.1$ & $<1$ & $1.1-2.2$ & Well \\
\hline HS-2 (Bed-2) & 70 & $3-5$ & $<1$ & $0.7-1.9$ & Not good \\
\hline HS-3 (Bed-3) & 50 & $3.2-4.3$ & 10 & $1-3$ & Not good \\
\hline HS-4 (Bed-4) & 30 & $1.9-2.4$ & 4 & $2.5-6.8$ & Not good \\
\hline HS-5 (1) (Bed-5) & 80 & $1.25-2.5$ & 6 & $1-1.7$ & Well \\
\hline HS-5 (2) (Bed-5) & 80 & $1.6-4.3$ & 6 & $1.3-2.2$ & Well \\
\hline HS-6 (Bed-6) & 50 & $2-3.8$ & 2.5 & 0.5 & Not good \\
\hline HS-7 (Bed-7) & 52 & $1-2.7$ & 7.5 & $0.45-1.4$ & Not good \\
\hline HS-8 (Bed-8) & 80 & $3.8-4.8$ & $<1$ & & Not good \\
\hline HS-9 (Bed-9) & 30 & $1-4$ & 17.5 & $0.4-3.4$ & Well \\
\hline HS-10 (Bed-10) & 50 & $1.5-3$ & 2.5 & $0.9-2$ & Well \\
\hline HS-11 (Bed-11) & 30 & $\begin{array}{l}0.4-0.7 / \\
1.4-3.7\end{array}$ & 17.5 & $1.2-2.5$ & Well \\
\hline HS-12 (1) (Bed-12) & 30 & $1-4.3$ & 25 & $1.2-2.5$ & Good \\
\hline HS-12 (2) (Bed-12) & 30 & $1.5-5$ & 15 & $0.7-1.2$ & Good \\
\hline HS-13 (1) (Bed-13) & 50 & $1-4.5$ & 7.5 & $0.7-1.2$ & Well \\
\hline HS-13 (2) (Bed-13) & 50 & $1-4.3$ & 7.5 & $1-1.3$ & Well \\
\hline
\end{tabular}

\subsection{Cementation}

Cementation in the coquina beachrock on the southern coast of Hanshan Island is well developed, but generally inorganic. One or two generations of cements can be recognized, which mostly but not entirely filled up the partial or whole interstices between shells and sands. Low Mg calcite cement is the most common in the Haishan coquina beachrock, as probably affected by beachrock uplift. Four kinds of cement are documented in the Haishan coquina beachrocks:

\subsubsection{Equant sparry calcite}

Sparry calcite grew between fragments/bioclasts or clasts/sands, showing a mosaic with anhedral form and straight rims. This kind of cement is generally common in the Haishan coquina beachrock and presents fine-to-block equigranular, anhedral-to-subhedral crystal forms. Forms with coarse and irregular brims (Fig. 9b) and with mosaic and straight brims (Fig. 11a) are both present. The size of equant crystals varies from mesocrystalline to macrocrystalline, ranging from 0.06 to $0.5 \mathrm{~mm}$. Equant spars show one or two generations that line or completely fill the pores.

Equant spar cement was directly precipitated on the shell fragments/bioclasts and terrigenous grains (Figs. 10c and 11a, b) or grew on the fibrous to blade-calcite crusts (Fig. 11a). This kind of cement also fills intraparticle pores within fragments/bioclasts and fractures in the siliciclastic grains. In some places, equant spar presents a drusiform growth form, with the crystals coarsening from the walls toward the centers of the pores. This fine-to-coarse equant sparry cement may represent low-magnesium calcite that was formed slowly in an undercurrent zone with saturated interstitial water.

\subsubsection{Fibrous to blade calcite rims (aragonite)}

This kind of cement grew vertically around the bioclasts, presenting a typically bunchy aggregate. It demonstrates isopachous rims composed of fibrous, blade and prismatic crystals standing perpendicular to shell fragment/bioclast and quartz grain surfaces. Isopachous rims generally grew outwardly and radially. In places, the isopachous rims fill the intraparticle pores in fragments/bioclasts, or, rarely, the intergranular pores. Typical fibrous calcite cements developed within the interstices between the biotic fragments/bioclasts. This fibrous calcite cement may have a relationship with the growth of red algae (Fig. 10d). The original cement for the latter was probably fibrous aragonite, some but all of which became recrystallized into blade calcite with granular structure. Short blade cements formed crusts between bivalve shell fragments and red algae (Fig. 9d). In some interstices with limited spaces, calcite cements present irregular granular crystals with mosaic contact (Fig. 11d); whereas those interstices with more spaces, blade calcite cements present thick columnar crystals growing from shell fragments and showing jigsaw-like contacts in the center (Fig. 12a). Two generations of cements can be observed in the coquina beachrocks, showing a first generation of fibrous to bladed calcite crusts (Fig. 11a, b, c) and a second generation of granular to block calcite cements (Fig. 11a, b, c). Generally, the cements from the second generation have larger calcite crystals than those of first generation.

\subsubsection{Micritic matrix}

Micrite matrix, consisting of cryptocrystalline carbonate, was left unevenly within the pores of silt and fine bioclasts and sands, and distributed in two types of occurrence: (1) small isolated irregular masses, forming patches between the grains (Fig. 12c); (2) common microcrystalline matrix, which partially or completely fill the pores (Fig. 12b). It is unevenly left in the pores of shell 

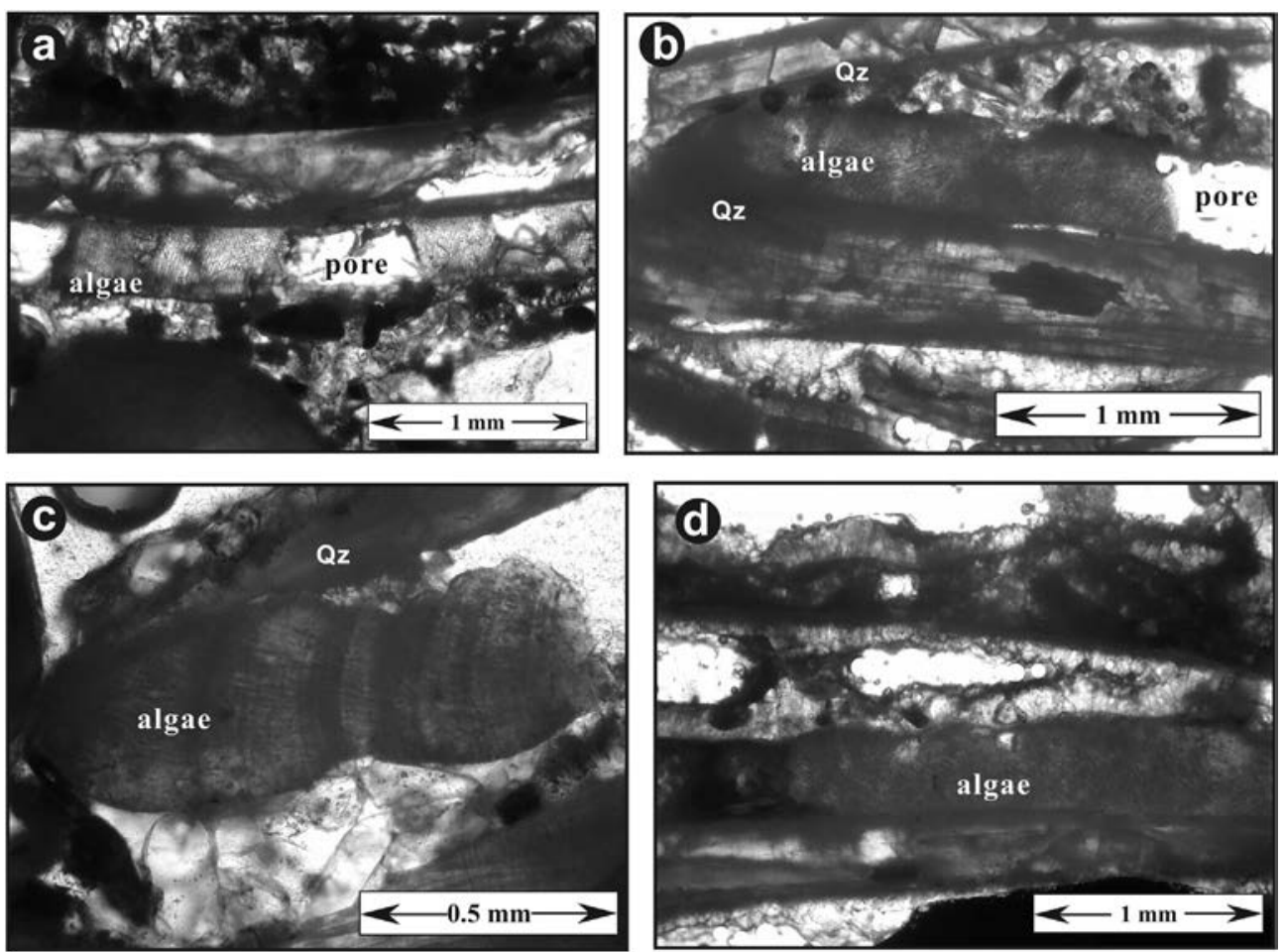

Fig. 9. Thin-section photomicrographs and in plane polarized. (a) Red algae occur undeneath the bivalve shell fragments, red algae fragments were dissolved by diagenesis; (b) red algae grow between bivalve shell fragments, partly dissolution occurs in shell fragments; (c) a red algae occur within the bivalve shell fragments, showing well growth bands; (d) red algae occur overgrow a bivalve shell fragment, short blade cements formed crusts between bivalve shell fragments and red algae.
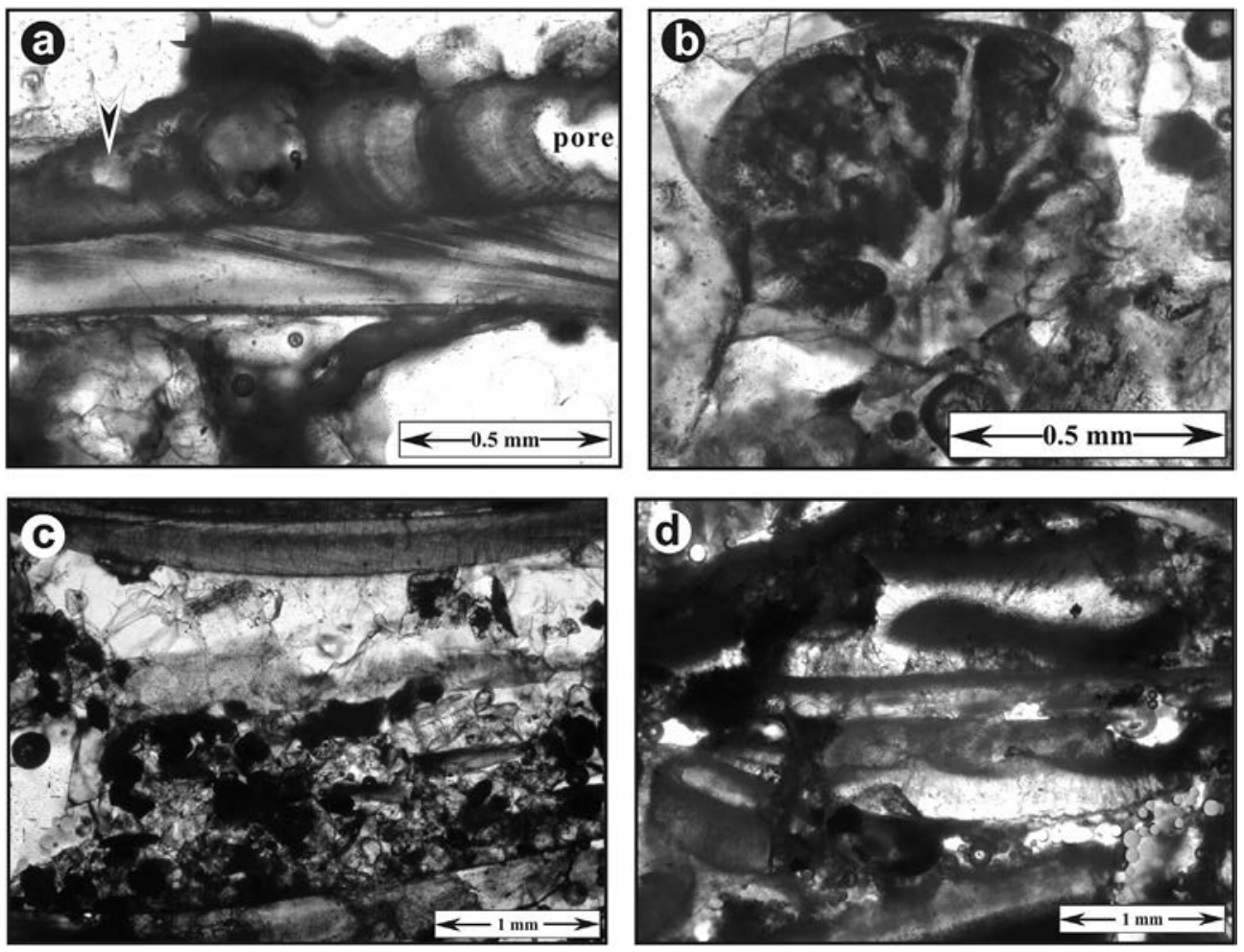

Fig. 10. Thin-section photomicrographs and in plane polarized. (a) Red algae overgrow a bivalve shell fragment, showing the longitudinal structure of red algae; (b) a coral within the coquina beachrock, showing transverse section of the coral; (c) the granular calcite cements developed within the interstices under the bivalve shell fragments; (d) fibrous calcite cements developed within the interstices between the biotic fragments/bioclasts, this fibrous calcite cements may have a relationships with the red algae growth. 

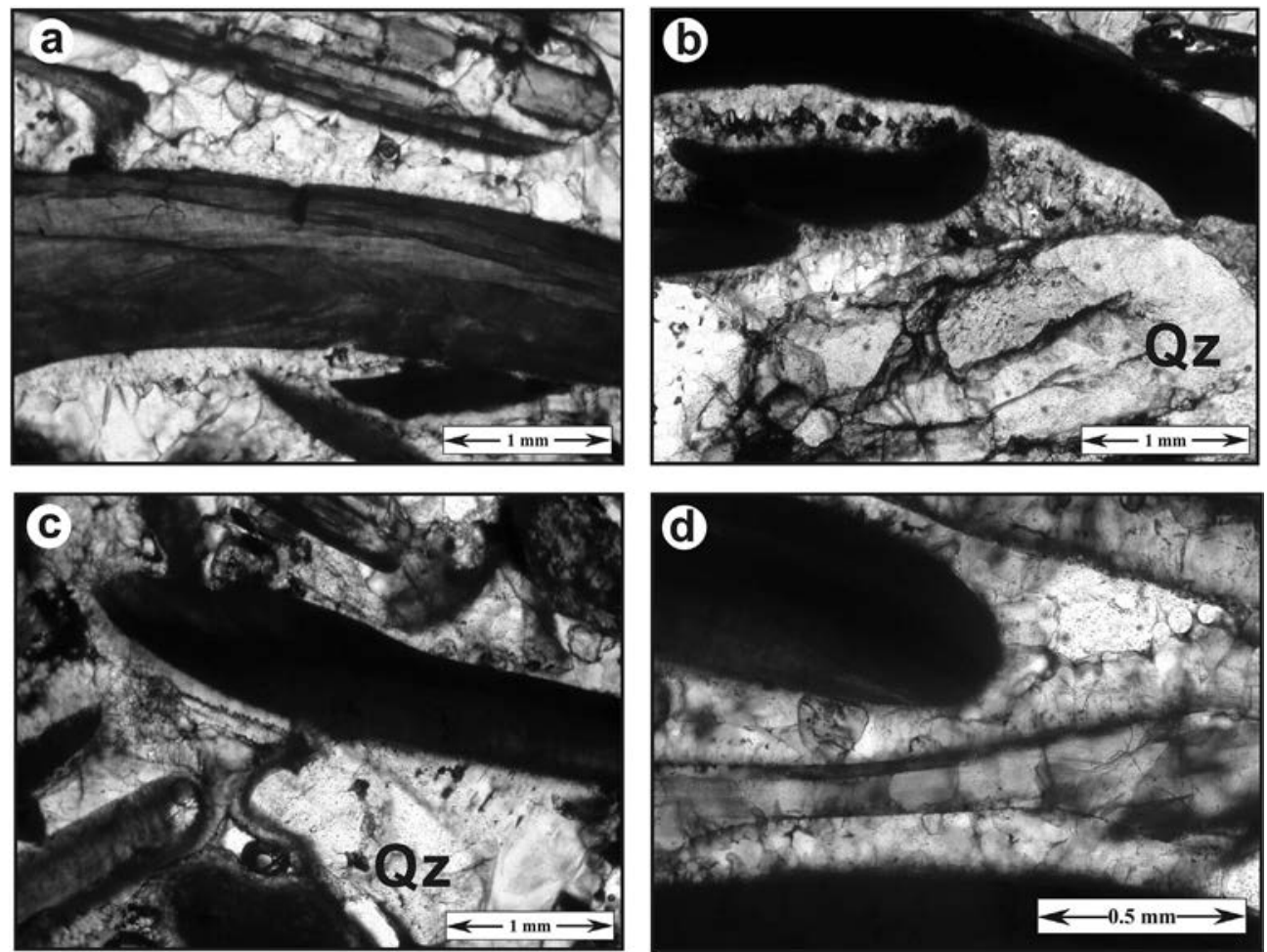

Fig. 11. Thin-section photomicrographs in plane polarized showing cementation within coquina beachrook. (a) Two generations of calcite cements grew between the bivalve shell fragments, radiaxial fibrous calcite cements grew on the shell fragments, and granular calcite cements then developed on the radiaxial fibrous calcite cements; (b) the granular calcite cements grew around bivalve shell fragments and quartz grains, calcite cements grew from fragments or quartz grains to the centre of the interstices; (c) cements around the grains and in the interstices showing two generations of calcites, fibrous calcite grew on the grains and granular calcite developed in the centre of interstices; (d) calcite cements present irregular granular crystals with mosaic contact in the interstices with limited spaces.
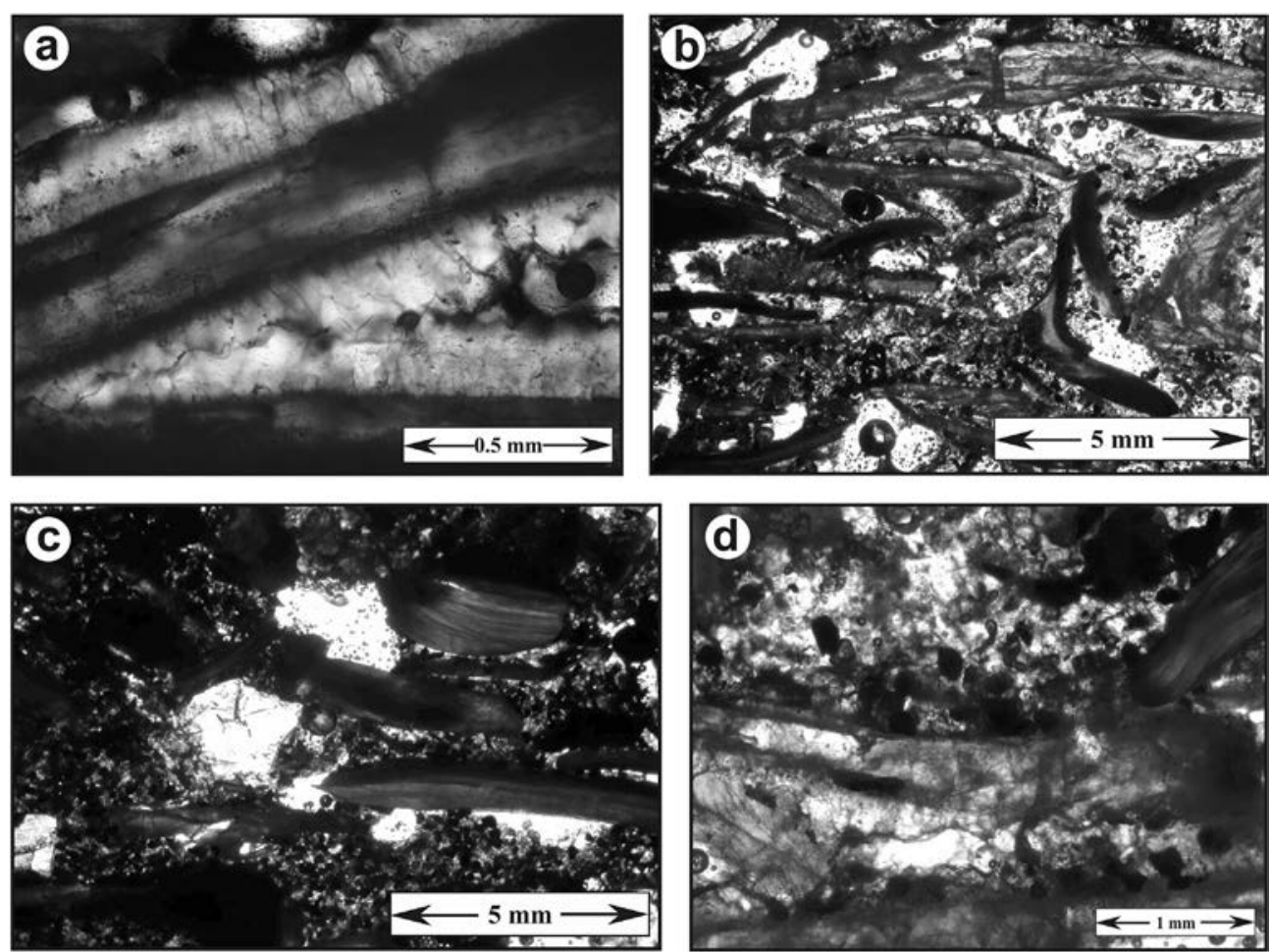

Fig. 12. Thin-section photomicrographs in plane polarized showing cementation within coquina beachrook. (a) Blade calcite crusts grew in the interstices between bivalve shel fragments, showing jigsaw-like contacts in the center; (b) micritic matrix infill of the interstices between bivalve shell fragments/bioclasts, or connect the fragments; (c) micritic matrix around the bivalve shell fragments and quartz grains; (d) enlarged Fig. 12b, some part of the matrix pedant over the fragments have been recrystallized into microcrystalline calcite. 


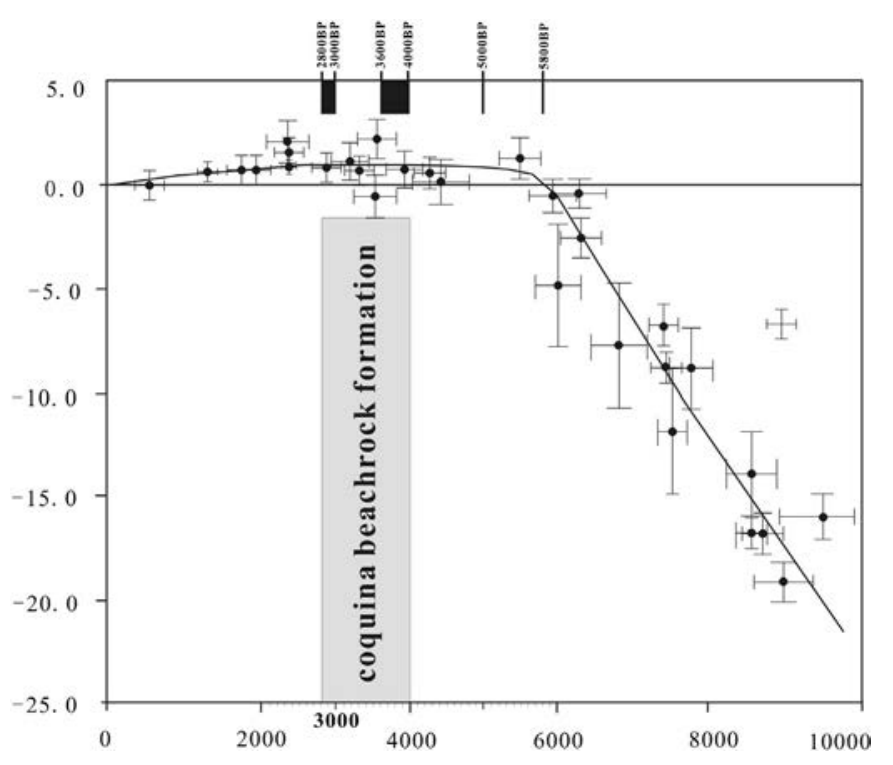

Fig. 13. Relative sea-level change in east Guangdong, China (modified from Zong, 2004).

fragments/bioclasts and quartz grains (Fig. 12b, c), and presents cryptocrystal texture and anhedral form (Fig. 12d). Both carbonate and siliciclastic grains are developed with a cryptocrystalline matrix. Alternation of carbonate grains by endolithic alga, bacteria or fungi is rarely observed (Fig. 9a, b). The component of micrite is dominated by calcium, but has no magnesium, indicating that micrite is aragonite deposited rapidly from the sedimentary environment.

\subsubsection{Ferruginous film}

Ferruginous film, in variable thicknesses, developed over the walls of pores and formed around the outside of the sparry calcite, corresponding to the modern underground water surface. Some grew around the outside of sparry calcite, indicating they were formed after formation of sparry calcite. Generally, the outer surface of sparry calcite is irregular due to solution. A similar ferruginous film also occurs within the calcareous cements. Typically, it is found developed on the top of bunchy aragonites cut by solution. Lastly, the columnar aragonites were formed on the ferruginous film. Bunchy and columnar aragonites separated by ferruginous film show different extinction positions, indicating they were formed at different times.

Early studies by Krumbein (1979) demonstrated that beach environments are microbiologically active, but the products of such microbial activity, especially in carbonate environments, are not well documented in the Haishan coquina beachrock of this study.

\section{Discussion}

Despite extensive reviews by Krumbein (1979), Stoddart et al. (1982) and Vousdoukas et al. (2007), the origin of beachrock is still not fully understood. Different hypotheses for its origin include physico-chemical precipitation, biologically induced precipitation, and a combination of both. Beachrock is most common in the intertidal zone on tropical beaches and has been described from many coastal and island beaches in the South China Sea. However, coquina beachrock is also relatively common in shallow marine environments along the northern coast of the South China Sea, and the Haishan coquina beachrock, east of Guangdong Province, is a typical example in this category. Potentially, as one of the youngest sedimentary rocks accumulating in the world, coquina brachrock records information regarding Holocene palaeogeography, sealevel change, palaeoclimate, early diagenesis, as well as neotectonic and coastal evolution.

Based on the Quaternary geology and geomorphology of the coquina beachrock from the southern coast of Haishan Island, its palaeogeographic significance was enhanced by factors associated with shoreline movement, sea-level change, dynamic variations in environmental conditions, and neotectonics.

Coquina beachrock is a kind of sedimentary rock peculiar to coastal areas, and its distribution records shoreline movements that reliably mark ancient shorelines (Mandic and Piller, 2001). Li (1988) classified the Holocene beachrock of coastal South China Sea into three basic types: (1) silted-prograded; (2) stable; and (3) eroded-retreated, based on the exposed positions of beachrock and relict coastal features. According to the geomorphologic analysis of beachrock occurrences, the Haishan coquina beachrock is classified as a silted-prograded type, because its distribution extends from the modern subtidal through the intertidal, and farther to intersect with inland hills. The compilation and interpretation of a shoreline record, as differentiated into relative age intervals, can be derived from the detailed analyses of large-scale topographic maps. Shoreline changes generally are mapped on the basis of lateral continuity and alignment, the condition of topographic preservation, and elevation. A bay is expanded when the shoreline shifts shoreward, and potentially a large amount of shell fragments/bioclasts can be deposited there. Conversely, a bay becomes reduced when the shoreline retreats seaward and pre-existing coquina deposits are eroded by wave action. The Haishan coquina beachrock reflects a horizontal shoreline change ranging from $800 \mathrm{~m}$ to $900 \mathrm{~m}$. The current shoreline retreated, and it is now about $800 \mathrm{~m}$ distal from the ancient shoreline. Bivalve shell fragments and other biotic grains with shallow marine sands were deposited to form a wave-built terrace (Pedoja et al., 2008). The upper part of the deposits of this terrace is associated with a notch at an elevation of $8 \pm 1 \mathrm{~m}$, meaning that Haishan Island was uplifted by about $8 \mathrm{~m}$. Two or three sequences of relict marine terrace shorelines have been recognized on the northern part of Haishan Island (Pedoja et al., 2008), none of which previously had been mapped. However, only one sequence with a wave-built terrace shoreline can be distinguished on the south margin of Haishan Island. Its shore angle is $8 \pm 1 \mathrm{~m}$ above mean sea level.

Beachrock occurrences have served to decipher Quaternary sealevel changes (Gischler and Lomando, 1997). Generally, beachrocks, including coquina beachrocks, are found in or close to the surf zone or mean sea level, considered to form within the intertidal zone and within the beach deposit. Exposure away from current coast is due to a recession of the coastline (Hopley, 1986). Coquina beachrock deposits are ideal as sea-level markers, because they are mostly developed in the intertidal zone. In addition, diagenetic features, evidence of atmospheric exposure, and other sedimentary characteristics of coquina beachrock succession may help to confirm sealevel fluctuations (Vieira and Ros, 2006). AMS ${ }^{14} \mathrm{C}$ data from the Haishan coquina beachrock is correspond with a Middle Holocene to early Late Holocene in age, as the subaerial outcrops of the coquina beachrocks are dated as $3720 \pm 30$ BP (Bed 5), $3530 \pm 30 \mathrm{BP}$ (Bed 10), and $2910 \pm 30 \mathrm{BP}$ (Bed 12), indicating the Haishan coquina beachrocks were formed during the middle and late Holocene. Taking into account the submarine or subsurface parts, the earliest deposition of coquina beachrocks may be much earlier than $3720 \pm 30$ BP. Besides an unknown amount of loss of beachrock sheets on their surfaces due to destruction by mechanical breaking, abrasion by sand and pebbles, and bioerosion by agriculture and farming, the landward and seaward parts of the Hanshan coquina beachrocks have not been truncated. The seaward part has an unknown extent offshore. The "remnants" of coquina 
beachrocks, however, still exhibit a vertical extension of cementation and record sea-level fluctuations. The highstand of sea-level was approximately from $4000 \mathrm{BP}$ to $2500 \mathrm{BP}$ on the east Guangdong coast of South China Sea, corresponding to the formation time of Haishan coquina beachrock (Fig. 13). The RSL curve from the east Guangdong coast shows a gradual decline towards the present-day level from approximately 2500 BP (Fig. 13), but this sea-level fall in Haishan Island is considered to begin after the highest sea-level about $2810 \pm 90 \mathrm{ka}$, as the inner edge of the coquina beachrocks is the farthest away from the current coast $(0.8-1.2 \mathrm{~km})$ and is associated with a notch at an elevation of $8 \pm 1 \mathrm{~m}$ (Pedoja et al., 2008), which may be chronologically equivalent to Bed 13 of Section $\mathrm{B}-\mathrm{B}^{\prime}$

On the east Guangdong coast, RSL reached the present-day height at around $5800 \mathrm{BP}$, continued to rise and attained the highest sea level (rose to about $1 \mathrm{~m}-1.5 \mathrm{~m}$ ) from $5000 \mathrm{BP}$ to $4000 \mathrm{BP}$, and remained high around $3000 \mathrm{BP}$, then gradually declined towards the present-day level by 2500 BP (Fig. 13). Coquina beachrooks on the southern coast of Haishan Island were developed during a highstand of sea level from about 4000 BP to 2800 BP (Fig. 13). According to the dating data from the most remote coquina beachrock that extends landward, it can be inferred that the relative sea level has gradually decreased to today's position since $2810 \pm 90 \mathrm{ka}$. Although the dating of Bed 5 of Section B$\mathrm{B}^{\prime}$ is $3720 \pm 30 \mathrm{BP}$, the ages of those coquina beachrocks that are not exposed in the subsurface or extend below sea level should be 4000 BP or much more older. The highest sea level for the development of Haishan coquina beachrock is around $2810 \pm 90 \mathrm{ka}$, after which sea level continued to fall. Generally, the formation period of the coquina beachrock is in a high sea level phase, although its depositional succession presents the variations in water depth. Relative sea level declined rapidly on the top of Bed 8 (Fig. 5), which may be related to tectonic activities. Sea level changes are reflected from the corresponding changes of the water depth, water energy and sedimentary rate recorded in the depositional succession of the coquina beachrock (Fig. 13, and Table 2).

Table 2

Water energy, sedimentary rate and water depth reflected by the characteristics of the coquina beachrock.

\begin{tabular}{|c|c|c|c|c|}
\hline & AMS ${ }^{14} \mathrm{C}$ dating & Water energy & $\begin{array}{l}\text { Sedimentary } \\
\text { rate }\end{array}$ & Water depth \\
\hline Bed-13 & $2810 \pm 90 \mathrm{ka}$ & Low to moderate & Rapid & $\begin{array}{l}\text { Deep to } \\
\text { shallow }\end{array}$ \\
\hline Bed-12 & $2910 \pm 30 \mathrm{BP}$ & Relatively strong & Rapid & Shallow \\
\hline Bed-11 & & $\begin{array}{l}\text { Moderate to } \\
\text { strong }\end{array}$ & Rapid & Shallow \\
\hline Bed-10 & $3530 \pm 30 \mathrm{BP}$ & Low & Low & Deep \\
\hline Bed-9 & & Low & Low & Deep \\
\hline Bed-8 & & $\begin{array}{l}\text { Moderate to } \\
\text { strong }\end{array}$ & $\begin{array}{l}\text { Moderate } \\
\text { to high }\end{array}$ & Shallow \\
\hline Bed-7 & & $\begin{array}{l}\text { Moderate to } \\
\text { strong }\end{array}$ & $\begin{array}{l}\text { Moderate } \\
\text { to high }\end{array}$ & $\begin{array}{l}\text { Deep to } \\
\text { shallow }\end{array}$ \\
\hline Bed-6 & & $\begin{array}{l}\text { Moderate to } \\
\text { strong }\end{array}$ & $\begin{array}{l}\text { Moderate } \\
\text { to high }\end{array}$ & $\begin{array}{l}\text { Relatively } \\
\text { deep }\end{array}$ \\
\hline Bed-5 & $3720 \pm 30 \mathrm{BP}$ & Strong & Rapid & Shallow \\
\hline Bed-4 & & Moderate & $\begin{array}{l}\text { Low to } \\
\text { moderate }\end{array}$ & $\begin{array}{l}\text { Relatively } \\
\text { deep }\end{array}$ \\
\hline Bed-3 & & Strong & Moderate & Shallow \\
\hline Bed-2 & & Low & Low & $\begin{array}{l}\text { Relatively } \\
\text { deep }\end{array}$ \\
\hline Bed-1 & & Moderate & Rapid & Shallow \\
\hline
\end{tabular}

Li (1988) compiled a sea-level curve on the basis of 58 locations of coquina and sandy beachrocks along the northern coast of South China Sea, and recognized three sea level fluctuations with peak values at 5000 BP, 3600 BP and 2000 BP, respectively.
All these data were collected from uplifted terraces with preserved beachrock and dated using conventional ${ }^{14} \mathrm{C}$. The subsided terraces are not exposed and the relevant data about terrace deposits is lacking. Therefore, beachrock as the sole marker of sea-level change can only reflect the sea-level changes in tectonic uplift zones. The sea level fluctuations proposed by Li (1988) are more or less similar to that of Zong (2004) (Fig. 13) with same peak values of sea level fluctuations at about 5000 BP, 3600$4000 \mathrm{BP}$, and 2800-3000 BP. Intervals of high sea level are not only reflected by paleogeography, but also by regional variations in erosion and deposition (Winker and Howard, 1977). It is believed that the Haishan coquina beachrock was formed during a phase of high sea level, when extensive cross bedding developed under the influence of ocean currents in a large southfacing embayment. Bivalves and gastropods samples for ${ }^{14} \mathrm{C}$ dating collected from the farthest extending side of coquina beachrock in land provide a non-calibrated age of $2810 \pm 90 \mathrm{ka}$ (Pedoja et al., 2008), indicating maximum sea level occurred from 2800 to $2900 \mathrm{BP}$.

The relationships between Holocene beachrock and paleoclimate are poorly understood. However, coquina beachrock in Haishan Island may be related to a climate with a high temperature and high rate of evaporation most favorable for beachrock formation. Hot and arid weather conditions may be conducive to calcium cementation (Taylor and Illing, 1969; Ward, 1973; Rey et al., 2005). Most of the Haishan coquina beachrock is composed of bivalve shell fragments/bioclasts with a rich calcium component that is beneficial for cementation. Holocene coquina and sandy beachrocks along the northern coast of the South China Sea were mostly formed during the late Middle Holocene and early Late Holocene (45002000 BP). Palynological and historical data also indicate a mainly hot-weather regime during this period in southern China with alternations between hot-humid and hot-dry conditions (Chen et al., 1982; Li et al., 1987). Therefore, the peak of beachrock formation along the northern coast of South China Sea was consistent with a hot climate.

Precipitation of carbonate cement in beach sediments is generally induced by inorganic or biological mediation (Strasser et al., 1989; Gischler and Lomando, 1997). Inorganic precipitation of carbonate cement is predominate in most beachrock cementation processes, with the initial aragonite cement altered to either high $\mathrm{Mg}$ or low $\mathrm{Mg}$ calcite during diagenesis in the meteoric environment (Tucker and Wright, 1990). However, the beach environments are microbiologically active (Krumbein, 1979; Gischler and Lomando, 1997), but the products of microbial activity are not well known in Holocene beachrock environments (Khadkikar and Rajshekhar, 2003). Marine algae and cyanobacteria have been documented as associated with intertidal coquina formation (Thompson et al., 2007). Cementation in the Haishan coquina beachrock is mostly related to inorganic processes. Microbial mediated cements are not distinctly developed. Fibrous calcite cements are observed to occur most closely with red coralline algae.

Neotectonic and sea-level ramifications of Holocene beachrock along the northern coast of South China Sea are closely related, but mutually constrained. Based on analysis of the Haishan coquina beachrock succession, a wide and continued subsidence phase, from about $4000 \mathrm{BP}$ to $2800 \mathrm{BP}$, formed the greater part of the submarine Haishan coquina beachrock. An uplift phase began after $3720 \mathrm{BP}$ and reached its maximum uplift with rapid sea-level fall during the deposition of aeolian sand bed on the top of Bed 8. After the continued subsidence until $2800 \mathrm{BP}$ with the highest sea level and the farthest shoreline towards the land, an uplift phase with relatively sea-level fall was persistent and led to more than $4 \mathrm{~m}$ thick coquina beachrock beds above current sea level. For the uplift rate of Haishan Island, Pedoja et al. (2008) calculated a rate for 
terrace 1 in the northeast part of Haishan Island (Sequence B), ranging from 0.08 to $0.20 \mathrm{~mm} / \mathrm{y}$, and considered that an extrapolation of the MISS 5e uplift rate $(0.08-0.20 \mathrm{~mm} / \mathrm{y}$ or $\mathrm{m} / \mathrm{ka}$ ) would imply $0.40-1 \mathrm{~m}$ vertical displacement for the last $5000 \mathrm{y}$.

\section{Conclusions}

1) Covering an area of $3.4 \mathrm{~km}^{2}$ with a thickness of more than $10 \mathrm{~m}$ on land and an unknown submarine area, Haishan coquina beachrock were formed in a semi-enclosed bay of marine origin surrounded by paleocoastal hills and islands during late Middle Holocene to early Late Holocene times.

2) A dominant regime of carbonates, mixed with minor siliciclasts, and a series of fining- and coarsening-upward shelly successions are referred to the Haishan coquina beachrock. Generally, layers are relatively well developed in the lower and middle part of the succession, but poorly developed in the upper part, probably representing different depositional rates.

3) Coquina beachrock deposits on the southern coast of Haishan Island are mainly composed of two types of sediments: fragments of bivalves, molluscs, red algae, bryozoans and benthic foraminifera, and terrigenous clasts of quartz and feldspars. The former is autochthonous and originally from marine biota in a semi-isolated bay, but the latter comes from the bedrock and subaerial coastal sediments eroded by water and wind.

4) Coquina beachrooks were developed during a highstand of sea level on the east Guangdong coast from about 4000 BP to 2800 BP. Relative sea level reached the present-day height at around $5800 \mathrm{BP}$, continued to rise and attained the highest sea level (rose to about $1 \mathrm{~m}-1.5 \mathrm{~m}$ ) from 5000 BP to 2500 BP. At Haishan Island, RSL gradually declined towards the presentday level by 2800 BP.

5) Cementation in the coquina beachrock of Hanshan Island is generally inorganic, and it is relatively well developed. One or two generations of cements can be recognized, which filled up the partial or whole interstices between shells and sands. Low $\mathrm{Mg}$ calcite cement is most common in the Haishan coquina beachrock, as this beachrock was the type related to uplift. The fibrous calcite cements may have a relationship with the growth of red algae.

\section{Acknowledgments}

The study was supported financially by the Guangdong Natural Science Foundation (Grant No. 9251030101000004, No. $8151030101000015)$, the National Natural Science Foundation of China (No. 40976030), and the National Marine Public Welfare Research Project (Grant No. 200805063-1). We thank Professor Markes Johnson and an anonymous referee for their thorough reviews and comments.

\section{References}

Bi, F.Z. Yuan, Y.S., 1988. A preliminary study of beachrocks and paleoclimate in China over the past 5000 years. The palaeoenvironment of East Asia from the Mid-Tertiary. In: Proceedings of the Second Conference. Centre of Asian Studies, University of Hong Kong, pp. 337-344.

Bi, F.Z., Yuan, Y.S., 1994. Holocene high beachrocks in South China and the structure of coastal large earthquakes. Donghai Marine Science 12 (3), 21-31 (in Chinese).

Bi, F.Z., Yuan, Y.S., Yin, Y.P., 1987. Study on the sedimentary facies of the Late Holocene "Beachrock Field" and on the characteristics of the coastal elevation and subsidence in the Haishan Island, Guangdong Province. Marine Geology and Quaternary Geology 7 (2), 45-57 (in Chinese).

Chen, C.H., Huang, B.L., Wang, M.L., 1982. Holocene geochronology research along the coast of Southern Fujian Province. Journal of Oceabnology in Taiwan Strait 1 (2), 64-72 (in Chinese).
Gischler, E., Lomando, J.A., 1997. Holocene cemented beach deposits in Belize. Sedimentary Geology 110 (3-4), 277-297.

Guangdong Geological Survey, 1965. Regional Geological Survey Report. Shantou Sheet, 1: 200000 (in Chinese).

Hopley, D., 1986. Beachrock as sea-level indicator. In: Vander Plassche, O. (Ed.), Sealevel Research: a Manual for the Collection and Evaluation of Data. Geo Books, Norwich, UK, pp. 157-173.

Huang, J.S., Zhu, Y.Z., Sha, Q.A., 1978. Primarily petrologic studies on modern beachrocks in Xisha Archipelago. Chinese Journal of Geology 4, 358-363 (in Chinese with English abstract).

Kenworthy, J.P., Santucci, V.L., 2006. A preliminary investigation of National Park Service paleontological resources in cultural resource contexts, Part 1: general overview. In: Lucas, S.G., Spielmann, J.A., Hester, P.M., Kenworthy, J.P., Santucci, V.L. (Eds.), America's Antiquities: 100 Years of Managing Fossils on Federal Lands. New Mexico Museum of Natural History and Science Bulletin 34. New Mexico Museum of Natural History and Science, Albuquerque, NM, pp. 70-76.

Khadkikar, A.S., Rajshekhar, C., 2003. Microbial cements in Holocene beachrocks of South Andaman Island, Bay of Bengal. Current Science 84 (7), 933-936.

Krumbein, W.E., 1979. Phototrophic and chemoorganotrophic activity of bacteria and algae related to beach rock formation and degradation (Gulf of Aqaba, Sinai). Geomicrobiology Journal 1 (2), 139-203.

Li, J.S., Fen, Y.J., 1998. A discussion on beach rocks in South China. Bulletin of Mineralogy, Petrology and Geochemistry 17 (3), 183-185 (in Chinese).

Li, P.R., 1988. Holocene beach rock in South China and its Paleogeographic significance. Marine Geology and Quaternary Geology 8 (4), 24-29 (in Chinese with English abstract).

Li, P.R., Huang, Z.G., Zong, Y.Q., 1987. Han River Delta. China Ocean Press, Beijing, pp. 1-296 (in Chinese).

Mandic, O., Piller, E.W., 2001. Pectinid coquinas and their palaeoenvironmental implications - examples from the early Miocene of northeastern Egypt. Palaeogeography, Palaeoclimatology, Palaeoecology 172 (3-4), 171-191.

Pedoja, K., Shen, J.W., Kershaw, S., Tang, C., 2008. Coastal Quaternary morphologies on the northern coast of the South China Sea, China, and their implications for current tectonic models: a review and preliminary study. Marine Geology 255 (3-4), 103-117.

Purser, B.H., 1980. Sédimentation et diagenèse des carbonates néritiques récents, vol. 1. Technip, Paris, p. 367.

Rey, D., Mohamed, K.J., Bernabeu, A., Rubio, B., Vilas, F., 2005. Early diagenesis of magnetic minerals in marine transitional environments: geochemical signatures of hydrodynamic forcing. Marine Geology 215 (3-4), 215-236.

Schmidt, W., Hoenstine, R.W., Knapp, M.S., Lane, E., Ogden, G.M., Scott, T.M., 1979. The limestone, dolomite and coquina resources of Florida. Florida Bureau of Geology Report of Investigation 88, 64.

Stoddart, D.R., Fosberg, F.R., Spellman, D.L., 1982. Cays of the Belize Barrier Reef and lagoon. Atoll Research Bulletin 256, 76.

Strasser, A., Davaud, E., Jedoui, Y.S., 1989. Carbonate cements in Holocene beachrock: example from Bahiret et Biban, southeastern Tunisia. Sedimentary Geology 62 (1), 89-100.

Sun, J.L., Xu, H.L., Qiu, X.L., Shen, J.-W., Zhan, W.H., 2006. Seidmentary characteristics of Holocene coquinite from the Haishan Island of eastern Guangdong Province and its Petrological implications. Marine Geology and Quaternary Geology 26 (6), 45-53 (in Chinese with English abstract).

Taylor, J.C.M., Illing, L.V., 1969. Holocene intertidal calcium carbonate cementation, Qatar, Persian Gulf. Sedimentology 12 (1-2), 69-107.

Thompson, N.L., Kelley, K.L., Davis, J.S., Cannon, E.A., Dang, A., 2007. Endolithic and epilithic algae and grazers of Coquina beachrock at Marineland, Florida. Florida Scientist 70 (2), 97-109.

Tucker, M.E., Wright, P., 1990. Carbonate Sedimentology. Blackwell, p. 482.

Vieira, M.M., Ros, L.F.D., 2006. Cementation patterns and generic implications of Holocene beachrocks from northeastern Brazil. Sedimentary Geology 192 (34), 207-230.

Vousdoukas, M.I., Velegrakis, A.F., Plomaritis, T.A., 2007. Beachrock occurrence, characteristics, formation mechanisms and impacts. Earth-Science Reviews 85, 23-46.

Wang, J.H., 1992. Some Beachrocks discovered along the Northwest Coast of Hainan Island and their significances. The Journal of Sun Yat-Sen University Forum (Natural Science Edition) 31 (1), 111-122 (in Chinese with English abstract).

Wang, J.H., 1997. Characteristics of dune rocks in the South China coast and their differences from beachrocks. Acta Sedimentologica Sinica 15 (1), 104-110 (in Chinese with English abstract).

Wang, W., Wu, Z., 1999. Identification of Holocene coastal dune rocks and beach rocks on South China coasts with artificial neural networks. Geographical Research 18 (4), 382-390 (in Chinese with English abstract).

Ward, W.C., 1973. Influence of climate on the early diagenesis of carbonate Eolianites. Geology 1 (4), 171-174.

Winker, C.D., Howard, J.D., 1977. Plio-Pleistocene palaeogeography of the Florida gulf coast interpreted from relict shorelines. Transaction Gulf Coast Association of Geological Societies 27 (23), 409-420.

Xie, Z.T., Chen, F., Liu, W.K., Shao, H.D., Xu, Z.F., Chen, Z.S., 1983. Fujian Holocene beachrock and the sea-level changes. Taiwan Strait 2 (1), 61-67.

Yang, S.R., Yang, S., 1996. Temporal and spatial distribution of beachrocks in China and climatic changes since $10 \mathrm{ka}$. Chinese Science Bulletin 41 (8), 723-727 (in Chinese with English abstract). 
Yuan, Y.S., Bi, F.Z., 1984. The origin of the highest beachrocks in central part of Fujian coast. Chinese Science Bulletin 29 (19), 1193-1196 (in Chinese with English abstract).

Zeng, Z.X., 1980. Briefly discussion on Chinese beachrocks. Chinese Quartery Research 5, 14-18 (in Chinese with English abstract).

Zhan, W.H., 2004. Modern Active Tectonics and Environmental Disaster in Northwestern South China Sea. Science Press, pp. 1-133.

Zhan, W.H., Liu, Y.X., Zhong, J.Q., Chen, X.S., 1998. Characteristics of Holocene beachrocks and sea level changes along coast of eastern Guangdong. Tropic Oceanology 17 (2), 24-31 (in Chinese with English abstract).
Zhao, X.T., Sha, Q.A., Fen, W.K., 1978. Holocene beachrocks in Hainan Island. Chinese Journal of Geology 2, 163-173 (in Chinese with English abstract).

Zhao, X.T., Zhang, J.W., Li, G.Y., 1984. The stage division of Chinese Holocene beachrocks and their response to the sea level change. Study on the Chinese coastal evolution. Fujian Science and Technology Publishing House, 101-107 (in Chinese with English abstract).

Zong, Y.Q., 2004. Mid-Holocene sea-level highstand along the Southeast Coast of China. Quaternary International 117, 55-67. 